\title{
A social work study for assessment of entrepreneurs' personal characteristics
}

\author{
Ahmad Ahmadkhani", Mehrnaz Paknezhad and Ahmad Maaroufkhani
}

Sama Technical Training Vocational Training College, Islamic Azad University, Zanjan Branch, Zanjan, Iran

\begin{tabular}{|c|c|}
\hline A R T I C L E I N F O & A B S T RA C T \\
\hline $\begin{array}{l}\text { Article history: } \\
\text { Received June 5, } 2011 \\
\text { Received in Revised form } \\
\text { August, 12, } 2011 \\
\text { Accepted } 15 \text { August } 2011 \\
\text { Available online } \\
18 \text { August } 2011 \\
\text { Keywords: } \\
\text { Entrepreneurship } \\
\text { Personality } \\
\text { Job creation } \\
\text { Creativity }\end{array}$ & $\begin{array}{l}\text { The personality of an entrepreneur plays an important role on the success of creating new ideas. } \\
\text { There are different characteristics such as courage, hardness, braveness, which could help an } \\
\text { entrepreneur reach his/her goals. In this paper, we present an empirical study to learn more } \\
\text { about students who are supposed to act as entrepreneur to create jobs in different fields of } \\
\text { accounting, computer science, mechanical engineering, etc. In this paper, There are seven } \\
\text { aspects of accepting reasonable risk, locus of control, the need for success, mental health } \\
\text { conditions, being pragmatic, tolerating ambiguity, dreaming and the sense of challenging in our } \\
\text { study to measure the level of entrepreneurship. We implement ANOVA test to measure } \\
\text { different entrepreneurship characteristics of students who study in various educational fields. } \\
\text { The case study is associated with Sama private university located in city of Zanjan/Iran. The } \\
\text { results indicate that there are not meaningful differences among pairwise comparison of many } \\
\text { engineering fields. }\end{array}$ \\
\hline
\end{tabular}

(C) 2012 Growing Science Ltd. All rights reserved.

\section{Introduction}

Personality is one of the most important characteristics of entrepreneurs and in many cases, this is the main criterion to decide whether an entrepreneur is entitled to receive loan from a financer or not. In fact, many banks' officials, venture capitals make financing decision solely based on the interview on entrepreneurs' personal characteristics. During the past few decades, there have been tremendous efforts on detecting important factors on the success of an entrepreneur. Zhao and Seibert (2006) presented meta-analytical methods to study the relationship between personality and entrepreneurial status.

They used personality variables from the previous studies and they categorized them based on the five-factor model of personality. They reported outstanding differences between entrepreneurs and managers on 4 personality dimensions such that entrepreneurs scored higher on conscientiousness and openness to experience and lower on neuroticism and agreeableness. However, they reported no difference for extraversion. They also reported negligible effect sizes for each personality dimension,

* Corresponding author. Tel: + 09358799109

E-mail addresses: adahmadkhani@gmail.com (A. Ahmadkhani) 
although the multivariate relationship for the full set of personality variables was reported to be moderate.

Schmitt-Rodermund (2004) introduced four aspects of parenting, personality, early entrepreneurial competence, and interests for the success of entrepreneurship. She reported an early start-up and an entrepreneurial personality of the founder as beneficial impacts. She emphasized on different implications of her findings, which are bank professionals dealing with venture capital loans.

Nicholson (1998) examined the question of whether there is an entrepreneurial leadership personality profile using an empirical investigation of the heads of the UK's top independent companies and comparing them with sample norms and a management control group. Wijbenga and van Witteloostuijn (2007) studied the impact of environmental dynamism on entrepreneurial locus of control-competitive strategy relationship and reported that internal entrepreneurs prefer product innovation strategies in stable environments, whereas external entrepreneurs opt for low-cost strategies in dynamic environments. Zampetakis (2008) studied the role of creativity and proactivity on perceived entrepreneurial desirability.

Zhou (2007) presented a comprehensive study on the effects of entrepreneurial proclivity and foreign market knowledge on early internationalization. Brush et al. (2009) introduced pathways to entrepreneurial growth by investigating the influence of management, marketing and money. They reported that fast-growing companies exhibit different rates and patterns of growth: some represent fast growth trajectories; some, slower, more measured rates; others, episodic periods of quick growth followed by sharp retrenchment. They also found that three key factors-management, marketing, and money-affected company growth across these patterns.

Obschonka et al. (2010) explained that entrepreneurial intention is the key success for new ideas. Ucbasaran et al. (2010) presented a study on the nature of entrepreneurial experience, business failure and comparative optimism. Lin (2006) presented a comparative study on the trends of entrepreneurial behaviors of enterprises in different strategies.

In this paper, we present an empirical study to measure different entrepreneurship characteristics of students who study in various educational fields. The study designs a questionnaire based on different criteria such as locus of control, need for success, dream, challenge, etc. The organization of this paper is as follows. We first present details of our questionnaire in section 2 and the results of our analysis are discussed in section 3. Finally, concluding remarks are given in the last to summarize the contribution of this paper.

\section{Problem statement}

In this paper, we select all students who were studying in different fields of accounting(AC), computer science(CS), electrical engineering (EE), mechanical engineering(ME), civil engineering(CE), metalorgy(MR) and drawing(DR). We have used the following formula to calculate the minimum number of sample size,

$$
n=\frac{N \times z_{\alpha / 2}^{2} \times p \times q}{\varepsilon^{2} \times(N-1)+z_{\alpha / 2}^{2} \times p \times q},
$$

where $N$ is the population size, $p=1-q$ represents the yes/no categories, $z_{\alpha / 2}$ is CDF of normal distribution and finally $\varepsilon$ is the error term. Since we have $p=0.5, z_{\alpha / 2}=1.96, \varepsilon=0.03$ and $N=1012$, the number of sample size is calculated as $n=133$. The questionnaire was designed based on Likert scale (Likert, 1932) from completely agree to completely disagree in four different scales. We have 
chosen nine personal characteristics for entrepreneurs with various scales representing very poor, poor, strong and very strong. Table 1 summarizes the numbers assigned to each item, respectively.

\section{Table 1}

Personal characteristics for entrepreneurs with various scales

\begin{tabular}{lcccc}
\hline Item & Very poor & Poor & Strong & Very strong \\
\hline Accepting reasonable risk (ARR) & {$[18-43)$} & {$[43-51)$} & {$[51-57)$} & {$[57-97)$} \\
Locus of control (LOC) & {$[17-49)$} & {$[49-55)$} & {$[55-60)$} & {$[60-77)$} \\
The need for success (NFS) & {$[15-44)$} & {$[44-48)$} & {$[48-53)$} & {$[53-64)$} \\
Mental health conditions (MHC) & {$[13-34)$} & {$[34-38)$} & {$[38-43)$} & {$[43-59)$} \\
Pragmatic (P) & {$[8-25)$} & {$[25-28)$} & {$[28-30)$} & {$[30-32)$} \\
Tolerating ambiguity (TA) & {$[11-18)$} & {$[18-22)$} & {$[22-26)$} & {$[26-44)$} \\
Dreaming (D) & {$[7-19)$} & {$[19-21)$} & {$[21-23)$} & {$[23-28)$} \\
Challenging (C) & {$[6-16)$} & {$[16-19)$} & {$[19-21)$} & {$[21-24)$} \\
Entrepreneur (E) & {$[95-264)$} & {$[264-283)$} & {$[283-303)$} & {$[303-380)$} \\
\hline
\end{tabular}

We have collected the average numbers for the data given in Table 1 for all different fields and the results are summarized in Table 2.

Table 2

The average score for each item associated with each field

\begin{tabular}{llllllllll}
\hline & \multicolumn{9}{c}{ Average number } \\
\hline Field & ARR & LOC & NFS & MHC & P & TA & D & C & E \\
\hline ME & 29.91 & 71.02 & 63.50 & 58.70 & 13.87 & 27.11 & 14.65 & 14.36 & 293.12 \\
EE & 24.04 & 42.76 & 33.45 & 32.54 & 19.65 & 31.64 & 16.57 & 11.16 & 207.81 \\
CE & 95.02 & 37.69 & 42.48 & 43.06 & 12.11 & 21.04 & 20.33 & 16.20 & 287.93 \\
AC & 48.48 & 47.22 & 35.98 & 36.84 & 20.24 & 25.44 & 11.91 & 7.81 & 324.01 \\
MR & 59.94 & 37.91 & 42.09 & 47.33 & 13.59 & 36.09 & 14.69 & 9.69 & 261.33 \\
DR & 38.80 & 76.57 & 52.69 & 22.04 & 17.91 & 17.05 & 18.38 & 8.83 & 252.27 \\
CS & 63.91 & 71.48 & 47.78 & 28.67 & 28.11 & 37.91 & 19.13 & 6.70 & 303.60 \\
\hline
\end{tabular}

Based on the limits we defined in Table 1 we can change the numbers in Table 2 into verbal terms of very poor(VP), poor(P), strong $(\mathrm{S})$ and very strong(VS) and the results are summarized in Table 3.

\section{Table 3}

The linguistic numbers for each item associated with each field

\begin{tabular}{|c|c|c|c|c|c|c|c|c|c|}
\hline & \multicolumn{9}{|c|}{ Average number } \\
\hline Field & ARR & LOC & NFS & MHC & $\mathrm{P}$ & TA & $\mathrm{D}$ & $\mathrm{C}$ & $\mathrm{E}$ \\
\hline $\mathrm{ME}$ & VP & VS & VS & VS & VP & VP & VP & VP & Average \\
\hline $\mathrm{EE}$ & VP & VP & VP & VP & VP & VS & VP & VP & Very poor \\
\hline $\mathrm{CE}$ & VS & VP & VP & S & VP & $P$ & $P$ & VP & Average \\
\hline $\mathrm{AC}$ & $\mathrm{P}$ & VP & VP & $\mathrm{P}$ & VP & S & VP & VP & Strong \\
\hline MR & VS & VP & VP & VS & VP & VS & VP & VP & Poor \\
\hline DR & VP & VS & $\mathrm{S}$ & VP & VP & VP & VP & VP & Poor \\
\hline $\mathrm{CS}$ & VS & VS & $\mathrm{P}$ & VP & $\mathrm{P}$ & VS & VP & VP & Strong \\
\hline
\end{tabular}

As we can observe from Table 2, accepting reasonable risk is strong for civil engineering, computer science and metallurgy. The issue of risk is poor for accounting and it is considered very poor for other fields. The sense of Locus of control is very strong among mechanical engineering, drawing and computer science and this item is very among other fields of sciences. The need for success is strong for mechanical engineering and drawing students, it is poor for computer science students and it is very poor among others. The sense of mental health condition is very strong among mechanical and metallurgy students, it is strong among civil engineering students, it is poor among accounting students and it is very poor among other students. The pragmatic aspect of computer science students is poor and this issue is very poor among students who are involved in other fields. Tolerating ambiguity is another aspect of our research, which is very strong among electrical, metallurgy and computer science students and it is strong among accounting students, poor among civil engineering 
students and very poor among other students. Dreaming is the other aspect, which is considered very poor among almost in all students. The challenging aspect is very poor among all students.

\section{The results}

In this section, we study whether this is any meaningful difference between entrepreneurial in different fields of engineering and sciences using Freedman ANOVA test (Freedman, 1940) where the level of significance is five percent. Table 4 summarizes the results of our pairwise comparison among all seven fields of educational studies.

\section{Table 4}

The summary of the implementation of Freedman test

\begin{tabular}{|c|c|c|c|}
\hline$\#$ & Hypothesis & P-value & $H_{1}$ \\
\hline 1 & $\begin{array}{l}\text { There is a meaningful difference for entrepreneurs' personal characteristics } \\
\text { between electrical and mechanical engineering students. }\end{array}$ & 0.074 & Reject \\
\hline 2 & $\begin{array}{l}\text { There is a meaningful difference for entrepreneurs' personal characteristics } \\
\text { between mechanical and civil engineering students. }\end{array}$ & 0.263 & Reject \\
\hline 3 & $\begin{array}{l}\text { There is a meaningful difference for entrepreneurs' personal characteristics } \\
\text { between mechanical engineering and accounting students. }\end{array}$ & 0.690 & Reject \\
\hline 4 & $\begin{array}{l}\text { There is a meaningful difference for entrepreneurs' personal characteristics } \\
\text { between mechanical and metallurgy engineering students. }\end{array}$ & 0.001 & Confirmed \\
\hline 5 & $\begin{array}{l}\text { There is a meaningful difference for entrepreneurs' personal characteristics } \\
\text { between mechanical engineering and drawing students. }\end{array}$ & 0.540 & Reject \\
\hline 6 & $\begin{array}{l}\text { There is a meaningful difference for entrepreneurs' personal characteristics } \\
\text { between computer and mechanical engineering students. }\end{array}$ & 0.001 & Confirmed \\
\hline 7 & $\begin{array}{l}\text { There is a meaningful difference for entrepreneurs' personal characteristics } \\
\text { between mechanical and civil engineering students. }\end{array}$ & 0.411 & Reject \\
\hline 8 & $\begin{array}{l}\text { There is a meaningful difference for entrepreneurs' personal characteristics } \\
\text { between electrical and accounting students. }\end{array}$ & 0.980 & Reject \\
\hline 9 & $\begin{array}{l}\text { There is a meaningful difference for entrepreneurs' personal characteristics } \\
\text { between electrical and metallurgy engineering students. }\end{array}$ & 0.810 & Reject \\
\hline 10 & $\begin{array}{l}\text { There is a meaningful difference for entrepreneurs' personal characteristics } \\
\text { between electrical and drawing engineering students. }\end{array}$ & 0.442 & Reject \\
\hline 11 & $\begin{array}{l}\text { There is a meaningful difference for entrepreneurs' personal characteristics } \\
\text { between electrical and computer engineering students. }\end{array}$ & 0.319 & Reject \\
\hline 12 & $\begin{array}{l}\text { There is a meaningful difference for entrepreneurs' personal characteristics } \\
\text { between civil engineering and accounting students. }\end{array}$ & 0.065 & Reject \\
\hline 13 & $\begin{array}{l}\text { There is a meaningful difference for entrepreneurs' personal characteristics } \\
\text { between civil and metallurgy engineering students. }\end{array}$ & 0.508 & Reject \\
\hline 14 & $\begin{array}{l}\text { There is a meaningful difference for entrepreneurs' personal characteristics } \\
\text { between civil and drawing engineering students. }\end{array}$ & 0.134 & Reject \\
\hline 15 & $\begin{array}{l}\text { There is a meaningful difference for entrepreneurs' personal characteristics } \\
\text { between civil and computer engineering students. }\end{array}$ & 0.180 & Reject \\
\hline 16 & $\begin{array}{l}\text { There is a meaningful difference for entrepreneurs' personal characteristics } \\
\text { between metallurgy engineering and accounting students. }\end{array}$ & 0.016 & Confirmed \\
\hline 17 & $\begin{array}{l}\text { There is a meaningful difference for entrepreneurs' personal characteristics } \\
\text { between drawing engineering and accounting students. }\end{array}$ & 0.100 & Reject \\
\hline 18 & $\begin{array}{l}\text { There is a meaningful difference for entrepreneurs' personal characteristics } \\
\text { between computer engineering and accounting students. }\end{array}$ & 0.336 & Reject \\
\hline 19 & $\begin{array}{l}\text { There is a meaningful difference for entrepreneurs' personal characteristics } \\
\text { between metallurgy and drawing engineering students. }\end{array}$ & 0.158 & Reject \\
\hline 20 & $\begin{array}{l}\text { There is a meaningful difference for entrepreneurs' personal characteristics } \\
\text { between metallurgy and computer engineering students. }\end{array}$ & 0.312 & Reject \\
\hline 21 & $\begin{array}{l}\text { There is a meaningful difference for entrepreneurs' personal characteristics } \\
\text { between drawing and computer engineering students. }\end{array}$ & 0.459 & Reject \\
\hline
\end{tabular}


As we can observe from the results of the implementation of Freedman ANOVA test, except three cases of 4, 6 and 16, we cannot make any specific judgment as there is any meaningful difference between different fields of engineering. However, there is a meaningful difference for entrepreneurs' personal characteristics between mechanical and metallurgy engineering students, between computer and mechanical engineering students and between metallurgy engineering and accounting students.

Based on the results we have calculated, accounting is believed to be number one in terms of the role of entrepreneurial leadership, computer science comes in the second position, mechanical engineering is one the third position, civil engineering, metallurgy, drawing and electronic engineering are in other descending positions.

\section{Conclusion}

In this paper, we have presented an empirical study to learn about personal characteristics of students who are supposed to act as entrepreneur to create jobs in seven fields of accounting, computer science, mechanical engineering, civil engineering, metallurgy engineering, electrical engineering and drawing. There were seven aspects of accepting reasonable risk, locus of control, the need for success, mental health conditions, being pragmatic, tolerating ambiguity, dreaming and the sense of challenging in our study to measure the level of entrepreneurship. We have implemented ANOVA test to measure different entrepreneurship characteristics of students who study in various educational fields. The results indicated that there were not meaningful differences among pairwise comparison of many engineering fields.

\section{Acknowledgment}

The present study was financially supported by a grant awarded by Islamic Azad University and the author would like to thank the officials for the financial support.

\section{References}

Brush, C.G., Ceru, D.J., \& Blackburn, R. (2009). Pathways to entrepreneurial growth: The influence of management, marketing, and money. Business Horizons, 52(5), 481-491.

Cronbach, L. J. (1951). Coefficient alpha and the internal structure of tests. Psychometrika, 16(3), 297-334.

Friedman, M. (1940). A comparison of alternative tests of significance for the problem of $\mathrm{m}$ rankings. The Annals of Mathematical Statistics, 11 (1), 86-92.

Likert, R. (1932). A Technique for the Measurement of Attitudes. Archives of Psychology, 140, 1-55.

Lin, W.B. (2006). A comparative study on the trends of entrepreneurial behaviors of enterprises in different strategies: Application of the social cognition theory. Expert Systems with Applications, 31(2), 207-220.

Nicholson, N. (1998). Personality and entrepreneurial leadership: A study of the heads of the UK's most successful independent companies. European Management Journal, 16(5), 529-539.

Obschonka, M., Silbereisen, R. K., Schmitt-Rodermund, E. (2010). Entrepreneurial intention as developmental outcome. Journal of Vocational Behavior, 77(1), 63-72.

Schmitt-Rodermund, E. (2004). Pathways to successful entrepreneurship: Parenting, personality, early entrepreneurial competence, and interests. Journal of Vocational Behavior, 65(3), 498-518.

Ucbasaran, D., Westhead, P., Wright, M., \& Flores, M. (2010). The nature of entrepreneurial experience, business failure and comparative optimism. Journal of Business Venturing, 25(6), 541555. 
Wijbenga, F.H., \& van Witteloostuijn, A. (2007). Entrepreneurial locus of control and competitive strategies - The moderating effect of environmental dynamism. Journal of Economic Psychology, 28(5), 566-589.

Zampetakis, L.A. (2008).The role of creativity and proactivity on perceived entrepreneurial desirability. Thinking Skills and Creativity, 3(2), 154-162.

Zhou, L. (2007). The effects of entrepreneurial proclivity and foreign market knowledge on early internationalization. Journal of World Business, 42(3), 281-293.

Zhao, H., \& Seibert, S. E. (2006). The Big Five Personality Dimensions and Entrepreneurial Status: A Meta-Analytical Review. Journal of Applied Psychology, 91(2), 259-271. 